\title{
SYNTHESIS OF SOL-GEL MATRICES FOR ENCAPSULATION OF ENZYMES USING AN AQUEOUS ROUTE
}

\author{
R.B. BHATIA *, C.J. BRINKER **, C.S. ASHLEY **, T.M. HARRIS *** \\ * University of New Mexico, Albuquerque, NM 87106; \\ ** Sandia National Laboratories, Albuquerque, NM 87185; \\ *** University of Tulsa, Tulsa, OK 74104.
}

\section{ABSTRACT}

Sol-gel matrices are promising host materials for potential chemical and biosensor applications. Previous studies have focused on modified sol-gel routes using alkoxides for encapsulation of enzymes. However the formation of alcohol as a byproduct during hydrolysis and condensation reactions poses limitations. We report the immobilization of glucose oxidase and peroxidase in silica prepared by an aqueous route which may provide a more favorable environment for the biomolecules.

A two step aqueous sol-gel procedure using sodium silicate as the precursor was developed to encapsulate the enzymes and the dye precursor, o-dianisidine. Glucose oxidase catalyzes the oxidation of glucose to give gluconic acid and hydrogen peroxide. Peroxidase then catalyzes the reaction of the dye precursor with hydrogen peroxide to produce a colored product. The kinetics of the coupled enzymatic reactions were monitored by optical spectroscopy and compared to those occurring in tetramethyl orthosilicate (TMOS) derived silica matrices developed by Yamanaka et al. [1]. Enhanced kinetics in the aqueous silicate matrices were related to differences in the host microstructures as elucidated by microstructural comparisons of the corresponding aerogels.

\section{INTRODUCTION}

Silica host matrices are being increasingly used for encapsulation of chemical dopants and biomolecules. Tremendous work is being done to develop these inorganic composites as chemical sensors and biosensors [2-4]. The issue that is critical to the development of a sensor is that the sensing component retains its function in the immobilized form. Sensor stability to operating conditions, sensor response time, and selectivity toward the analyte are other important considerations for the sensor development. For biosensor applications in particular, the enzymes find a more stable environment upon encapsulation in a silica host. The polymeric framework grows around the biomolecule and cages it, thus preventing the enzyme from aggregation and unfolding. The porous matrix further acts as a reservoir for water to maintain enzyme activity in the host. The pore channels of silica allow smaller analyte molecules to enter the matrix and participate in the sensor reaction while, at the same time, excluding the larger microbes. Protection from microbial attack is an important advantage of inorganic hosts over organic polymer hosts. Other advantages of silica matrices over organic supports include physical rigidity of the host, chemical inertness, thermal stability, optical transparency and negligible swelling in solvents.

Silica glass is prepared by hydrolysis and condensation reactions of organometallic compounds such as $\mathrm{Si}\left(\mathrm{OCH}_{3}\right)_{4}$, tetramethyl orthosilicate [5]. A modified sol-gel route starting 


\section{DISCLAIMER}

This report was prepared as an account of work sponsored by an agency of the United States Government. Neither the United States Government nor any agency thereof, nor any of their employees, make any warranty, express or implied, or assumes any legal liability or responsibility for the accuracy, completeness, or usefulness of any information, apparatus, product, or process disclosed, or represents that its use would not infringe privately owned rights. Reference herein to any specific commercial product, process, or service by trade name, trademark, manufacturer, or otherwise does not necessarily constitute or imply its endorsement, recommendation, or favoring by the United States Governrnent or any agency thereof. The views and opinions of authors expressed herein do not necessarily state or reflect those of the United States Government or any agency thereof. 


\section{DISCLAIMER}

Portions of this document may be illegible electronic image products. Images are produced from the best available original document. 
from TMOS, developed by Ellerby et al. [6], has been extensively followed for enzyme immobilization. The first step involves an acid catalyzed reaction to form a low $\mathrm{pH}$ sol. The enzymes are then introduced with a suitable buffer to facilitate gelation of the network at a pH compatible with the enzyme. However, the formation of alcohol as a byproduct during the hydrolysis and condensation reactions still poses problems for encapsulating biomolecules that may not be stable in alcohol. Thus, there exists a need to find a system that is more favorable for immobilization of bioactive species.

In our work, a new aqueous route for synthesis of bio-inorganic composites using sodium silicate (also known as water glass) as a precursor was developed. The use of aqueous solutions of sodium silicate at varying $\mathrm{pH}$ values as a silica precursor has been previously studied $[7,8]$. However, we have modified conventional sodium silicate processing to develop a two-step method that makes the processing compatible for addition of enzyme. Optical spectroscopic tools were used to check retention of activity of the enzyme in the host. Further comparisons were made in terms of overall kinetics of the enzyme in gels derived from the different precursors, i.e., sodium silicate and TMOS. Corresponding aerogels were prepared to characterize the host microstructures of gels from both the conventional and aqueous route and hence explain the enhanced kinetics observed in gels from the aqueous route.

\section{EXPERIMENTAL}

\section{Preparation of Bio-inorganic Composites}

Silicate sols were prepared from sodium silicate $\left[\left(3.25 \mathrm{SiO}_{2}: \mathrm{Na}_{2} \mathrm{O}\right), \mathrm{H}_{2} \mathrm{O}\right]$ solutions. The ratio of 3.25 was selected to minimize the volume of acid required for neutralization of alkali. To prepare $50 \mathrm{ml}$ of the final gel, $11.5 \mathrm{~g}$ of sodium silicate solution was combined with $34 \mathrm{ml}$ of DI water. To this aqueous solution, $15.4 \mathrm{~g}$ of strongly acidic cation exchange resin was added while stirring to bring the $\mathrm{pH}$ of the solution to a value of 4 . The resin was then removed by vacuum filtration. $2.0 \mathrm{M} \mathrm{HCl}(0.3 \mathrm{ml})$ was added to the filtrate to adjust the $\mathrm{pH}$ to 2.0 . The low $\mathrm{pH}$ value was necessary to enhance aging. The resin was regenerated as needed with $500 \mathrm{ml}$ of $4 \%$ acid per $100 \mathrm{~g}$ of used resin. To avoid use of resin, an alternate two-step procedure was followed where hydrochloric acid was used to prepare the low $\mathrm{pH}$ sol. An aqueous solution of sodium silicate was added in small aliquots to $2.0 \mathrm{M} \mathrm{HCl}$ (with vigorous stirring) to obtain a $\mathrm{SiO}_{2}: \mathrm{H}_{2} \mathrm{O}: \mathrm{HCl}$ molar ratio of 1:50:0.7.

For both procedures, the second step involved the addition of enzyme in buffer solution. Two types of gels were synthesized for the purpose of characterization. For the first type of gel, $0.096 \mathrm{mg}$ glucose oxidase was added to $0.75 \mathrm{ml}$ of $\mathrm{pH} 7$ phosphate buffer $(1.0 \mathrm{M})$. The $\mathrm{pH}$ of the sol was then raised by adding the enzyme-buffer solution to $5.25 \mathrm{ml}$ of the sol. Before gelation occurred, the buffered sol was quickly transferred to the corresponding mold. The gels were formed in cuvettes $(1 \mathrm{~cm} \times 1 \mathrm{~cm} \times 2 \mathrm{~cm})$ and in cylindrical polypropylene tubes $(1.5 \mathrm{~cm} \times 6$ $\mathrm{cm})$. Gelation took place in $\sim 5$ minutes.

A second type of gel was prepared to check bio-activity of the trapped enzymes. This involved the use of a sensor scheme using coupled enzymatic reactions as below [9] :-

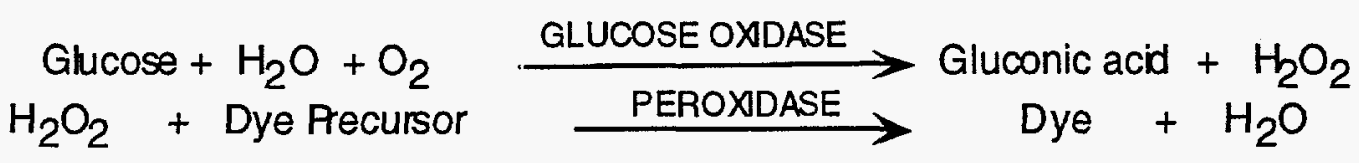


Glucose oxidase and peroxidase, at concentrations of $10^{-8} \mathrm{M}$ and $10^{-7} \mathrm{M}$, respectively, were added to $5.5 \mathrm{ml}$ of the phosphate buffer at $\mathrm{pH} 7$. A dye precursor solution of o-dianisidine hydrochloride in phosphate buffer $(6 \mathrm{mg} / \mathrm{ml})$ was prepared. The phosphate buffer with enzymes and $0.5 \mathrm{ml}$ of dye precursor solution were added to $42 \mathrm{ml}$ of the sol. The gels were formed in cuvettes and stored at $4^{\circ} \mathrm{C}$. All enzyme-buffer additions were made at ice bath temperatures. Corresponding gels derived from TMOS with the enzymes and dye precursor were prepared for purposes of comparison using the conventional route. A detailed procedure for preparing gels derived from TMOS is reported by Yamanaka et al. [1]. A comparison of the processing steps for the aqueous and conventional routes is shown below in Fig 1.

CONVENTIONAL ROUTE

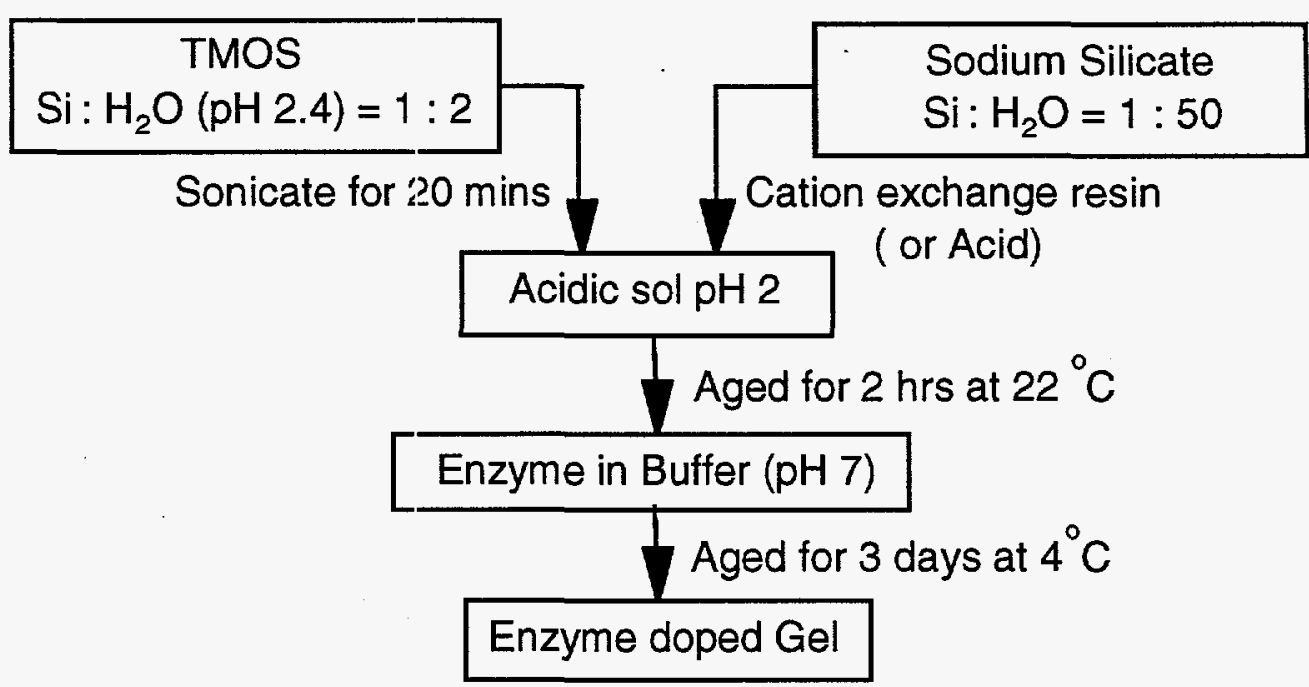

Figure 1. Schematic for sol-gel processing steps to prepare enzyme doped gels by the aqueous vs. the conventional route.

\section{Optical Spectroscopy}

The optical spectra for the enzyme glucose oxidase were recorded using a Lambda $900 \mathrm{UV}$ Vis spectrophotometer in the 300 to $550 \mathrm{~nm}$ range. The absorption spectrum of the enzyme in buffer $(\mathrm{pH} \mathrm{7)}$ and in the entrapped form in an aqueous gel was recorded. The absorbance of the enzyme was determined by comparing it to a reference, i.e., the buffer solution or the silica gel without the enzyme.

The kinetics of the immobilized enzyme was measured using the coupled enzymatic reactions. In the course of the second reaction of the enzymatic reaction scheme, o-dianisidine gets oxidized, and the change in absorbance of the oxidized dye at $436 \mathrm{~nm}$ is a measure of the enzymatic activity. Thus, to measure the kinetics of the encapsulated enzyme, glucose ( $10 \mathrm{wt} \%)$ was added in the cuvette with the sample to be run. The formation of the dye was monitored by an absorbance vs. time spectrum, rneasurements being recorded every 10 seconds.

\section{Aerogel Preparation and Characterization}

The cylindrical wet gels, prepared from TMOS and sodium silicate were washed with $\mathrm{pH} 7$ buffer for two hours to desorb arly enzyme molecules not bound in the pores of the gel. The 
solvent in the pores of the gels was then replaced with amyl acetate by pore fluid exchanges. The gels were placed in a Polaron critical point dryer (CPD) that was pre-filled to half its volume with amyl acetate. The $\mathrm{CPD}$ chamber was sealed and liquid $\mathrm{CO}_{2}\left(18^{\circ} \mathrm{C}, 950 \mathrm{psi}\right)$ was allowed to enter the chamber and displace the amyl acetate. The samples were flushed with liquid $\mathrm{CO}_{2} 3-4$ times to completely replace the pore fluid with $\mathrm{CO}_{2}$. Between the flush cycles, the chamber was sealed to allow soaking in liquid $\mathrm{CO}_{2}$. The temperature was increased to $36^{\circ} \mathrm{C}$ over a period of about one hour causing the pressure to rise to $1150 \mathrm{psi}$, well above the critical temperature and pressure of $31^{\circ} \mathrm{C}$ and $1050 \mathrm{psi}[10]$. The chamber was held above the critical point for $\sim 0.5$ hour after which time the $\mathrm{CO}_{2}$ was vented to obtain the aerogels.

The nitrogen sorption technique was employed to characterize the aerogels using the Micromeritics ASAP (Accelerated Surface Area and Porosimetry) 2100 Instrument. Prior to analysis, the aerogels were degassed overnight at $1 \mathrm{~mm} \mathrm{Hg}$ pressure. The BET and BJH models were used to obtain surface area, pore size distribution and pore volume of the gels.

The enzyme doped aerogels were then tested for activity using the o-dianisidine colorimetric assay. The enzyme doped aerogels were placed in a solution of glucose to which, dye precursor and the peroxidase solution in buffer was added to it.

\section{RESULTS AND DISCUSSION}

The spectrum of the encapsulated enzyme in the wet gel prepared by the aqueous route and the characteristic absorption spectrum of the enzyme in solution is as shown in Fig. 2 . Absorbance is significant in the visible region with maximum values at $380 \mathrm{~nm}$ and $452 \mathrm{~nm}$.

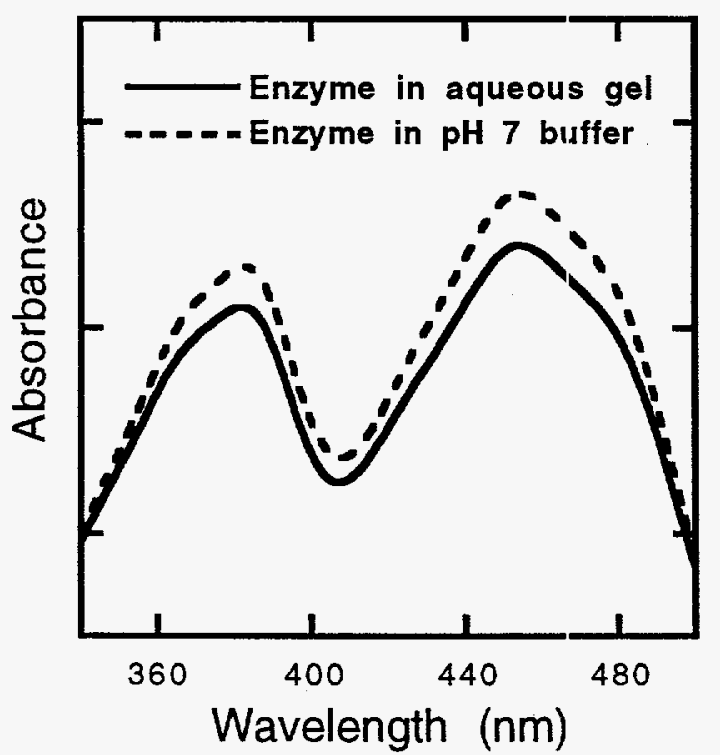

Figure 2. Optical spectra of glucose oxidase in $\mathrm{pH} 7$ buffer and in the encapsulated form in a gel prepared by the aqueous route starting from sodium silicate.

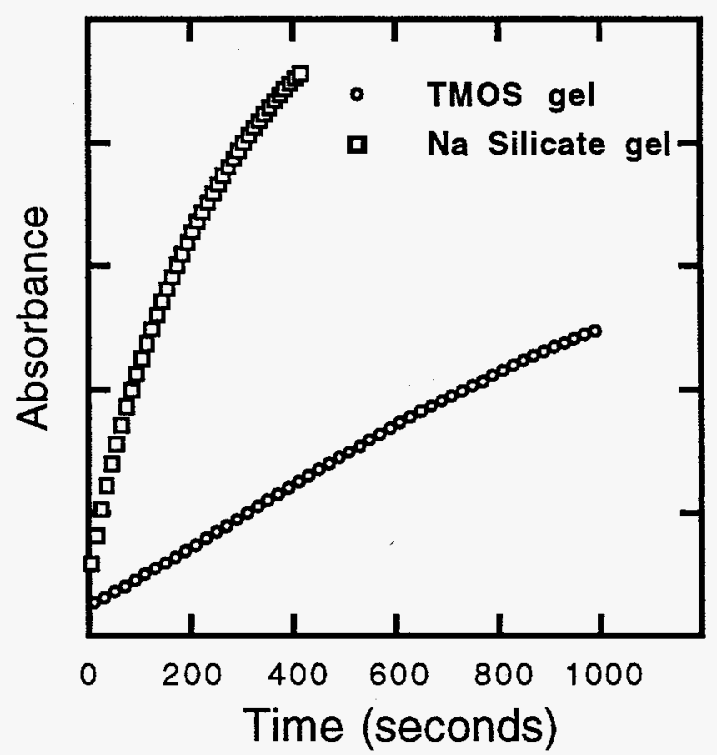

Figure 3. Formation of dye measured as a function of time in wet gels produced by the conventional route starting from TMOS as compared to gels by the aqueous route.

The absorption spectra of the enzyme in the silica host matrix as compared to the enzyme in buffer does not show any wavelength shifts in peak adsorption or peak broadening. This 
indicates that the protein has not undergone any protein unfolding or changes in structural integrity upon encapsulation.

The absorption spectrum for the formation of the dye in the enzyme doped gels is shown in Fig. 3. Overall apparent rate of reaction was calculated from the slope of the linear regression of the plot. Enhanced kinetics wese observed in the gels prepared by the aqueous route as compared to the conventional route gels from TMOS. The fact that the coupled enzymatic reaction scheme is demonstrated by the encapsulated enzymes further proves that the protein conformation is retained upon confinement within the matrix.

To understand the faster response in gels prepared by the aqueous route, aerogels were prepared from the wet gels as discussed in the experimental section. The pore fluid is extracted using liquid $\mathrm{CO}_{2}$ at supercritical conditions and replaced with air to form an aerogel. At the critical point, liquid interfaces are eliminated, thereby reducing capillary stress and preventing collapse of the pores. The BJH desorption isotherms as plotted in Fig. 4. were used to obtain the pore size distribution and accessible porosity of the gels.

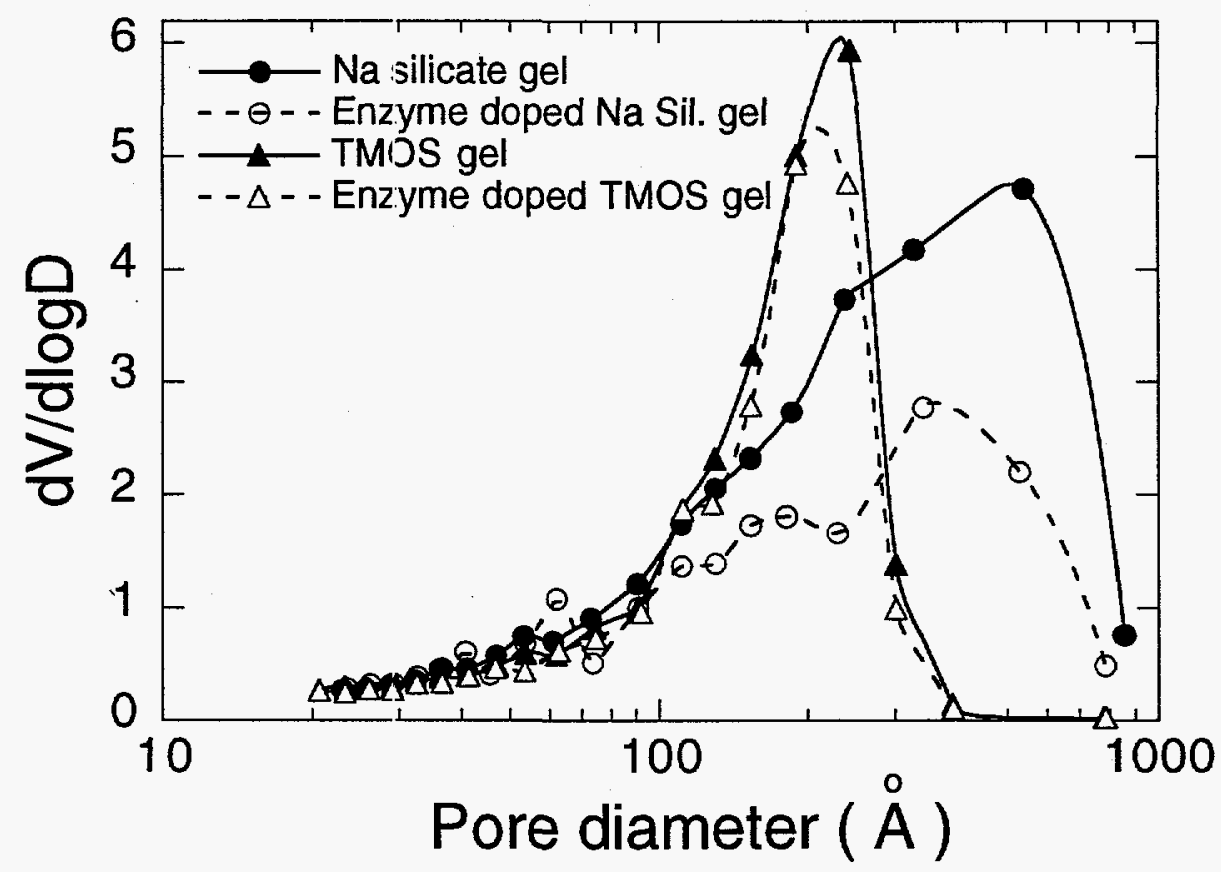

Figure 4. Microstructure of aerogels synthesized from the aqueous and conventional route and the corresponding glucose oxidase doped aerogels as obtained from the $\mathrm{BJH}$ desorption isotherm

It is evident from Fig. 4 that the gels obtained by the aqueous route have a much wider pore size distribution and higher accessible porosity as compared to the gels obtained from the conventional route. The slower sensor response can be explained by diffusional limitations and pore volume limitations that may be imposed in the gels derived from TMOS [11]. In the scheme of coupled enzymatic reactions, the first step involves diffusion of the substrate, i.e., glucose in our system, to the entrapped enzyme. Once the substrate binds to the enzyme, an enzyme-substrate complex is formed. The enzyme-substrate complex then results in the product and the free enzyme. Further, the product needs to diffuse to the site of the second enzyme, peroxidase which catalyzes the second reaction to form the dye from the corresponding dye precursors. A larger pore size distribution in aqueous gels may point to the dye molecules and enzymes being encapsulated in closer proximity in the aqueous gels as compared to the TMOS 
gels. Higher accessible porosity and pore volume allows enhanced diffusion of the analytes and greater accessibility to the dye precursor and active enzyme sites. Thus in our opinion, the differences in the microstructures of the gels may explain faster response in the aqueous gels vs. the gels from the conventional route.

Further, we were able to show retention of glucose oxidase activity in the aerogels by observing dye formation upon immersion of the gels in a glucose solution. This result demonstrates that the encapsulated enzyme is active in the aerogels on supercritical extraction of the solvents from the pores.

\section{SUMMARY}

A new approach to the formation of bio-inorganic composites is investigated in our work. By starting with sodium silicate, alcohol is completely eliminated in the processing of the silica gels. This method may prove useful in encapsulating biomolecules or other dopants which are unstable in alcohol. Enzymes encapsulated in gels prepared by the aqueous route retain chemical functionality and reactivity. Faster response is observed in gels prepared by the aqueous route as compared to the conventional TMOS route. The observed differences in response time may be explained by microstructural differences of the host matrices. To date, enzyme activity has been demonstrated within wet silica gels. Retention of enzyme activity in aerogels may prove useful in biosensor applications where the sensor must be exposed to a range of temperature/humidity conditions.

\section{REFERENCES}

1. S.A. Yamanaka, F. Nishida, L.M. Ellerby, C.R. Nishida, B.S. Dunn, J.S. Valentine and J.I. Zink, Chemistry of Materials, 4 (3), 495, (1992).

2. O. Lev, M. Tsionsky, L. Rabinovich, V. Glezer, S. Sampath, I. Pankratov, and J. Gun, Analytical Chemistry, 67, 22A, (1995).

3. J. Lin and C.W. Brown, Trends in Analytical Chemistry, 16 (4), 200, (1997).

4. C.M. Ingersoll and F.V. Bright, Chemtech, 27 (1), 26, (1997).

5. C.J. Brinker, G. Scherer in Sol-Gel Science: The Physics and Chemistry of Sol-Gel Processing, Academic Press, San Diego, (1990).

6. L.M. Ellerby, C.R. Nishida, F. Nishida, S.A. Yamanaka, B.S. Dunn, J.S. Valentine and J.F. Zink, Science, 255, 1113, (1992).

7. R.K. Iler in The Chemistry of Silica : Solubility, Polymerization, Colloid and Surface Properties, and Biochemistry. (John Wiley, New York, 1989), pp. 172-220.

8. K. Okkerse in Physical and Chemical Aspects of Adsorbents and Catalysts, edited by B.G. Linsen (Academic Press, London, 1970), pp. 215-228.

9. H.U. Bergmeyer in Methods of enzymatic analysis, (Academic Press, New York, , 1965) pp. 123-124.

10. P.H. Tewari, A.J. Hunt and K.D. Lofftus, Mater. Lett., 3, 363, (1985).

11. B.C. Dave, B. Dunn, J.S Valentine and J.I. Zink, ACS Symp. Series, 622, 351, (1996). 